\title{
When the Chinese intellectual property system hits 35
}

\author{
Peter $\mathrm{K} \mathrm{Yu}$ * \\ Professor of Law, Professor of Communication and Director, Center for Law and Intellectual Property, \\ Texas A\&M University
}

This article explores what it means for the Chinese intellectual property system to hit 35. It begins by briefly recapturing the system's three phases of development. It discusses the system's evolution from its birth all the way to the present. The article then explores three different meanings of a middle-aged Chinese intellectual property system - one for intellectual property reform, one for China, and one for the TRIPS Agreement and the global intellectual property community.

Keywords: China, intellectual property, international trade, legal reform, TRIPS Agreement, WTO

\section{INTRODUCTION}

In 1982, China promulgated its first modern intellectual property law, offering protection to trademarks. Since then, China adopted the Patent Law in 1984, the Copyright Law in 1990 and the Anti-Unfair Competition Law in 1993. In December 2001, China finally became a member of the World Trade Organization (WTO), assuming obligations under the Agreement on Trade-Related Aspects of Intellectual Property Rights (TRIPS Agreement).

One can certainly debate about the actual age of the Chinese intellectual property system. Some commentators, for instance, have traced the system back to the end of the Qing dynasty, the Hundred Days' Reform in 1898, the Taiping Rebellion (1850-64), or even the imperial rights to smelt iron, distil salt or mint coin granted more than two millennia ago. ${ }^{1}$ Nevertheless, as far as the modern Chinese intellectual property system is concerned, it would not be too far-fetched to suggest that the system began in the early to mid-1980s and is now entering, or approaching, its middle age. What exactly does a middle-aged Chinese intellectual property system mean? Will the system hit its prime? Or is it about to face a hard-to-predict mid-life crisis?

This article explores what it means for the Chinese intellectual property system to hit 35. Although it dates the system back to the 1982 Trademark Law, the analysis would hold up even if the system were traced back to the beginning of China's membership of the World Intellectual Property Organization (WIPO) in 1980 or the adoption of the Patent Law in 1984. This article begins by briefly recapturing the three phases of development of the Chinese intellectual property system. In the style of David Copperfield, it discusses the system's evolution from its birth all the way to

* Copyright (C) 2018 Peter K Yu.

1. $\mathrm{PK} \mathrm{Yu}$, 'Building the Ladder: Three Decades of Development of the Chinese Patent System’ (2013) 5 WIPO J 1, 3-4. 
the present. The article then explores three different meanings of a middle-aged Chinese intellectual property system - one for intellectual property reform, one for China and one for the TRIPS Agreement and the global intellectual property community.

\section{THE FIRST 35 YEARS}

The development of the modern Chinese intellectual property system can be divided into three distinct phases (and four if one counts the developments before the adoption of the country's first modern intellectual property statute) ${ }^{2}$ The first phase, the imitation and transplantation phase, began when China re-opened its market to foreign trade in the late 1970s. Often mentioned alongside this re-opening is the signing of the Agreement on Trade Relations between the United States of America and the People's Republic of China. Adopted in 1979, this landmark agreement called for the reciprocal protection of copyrights, patents and trademarks owned by the nationals of the other party.

Shortly after the re-opening, China joined WIPO in 1980. It also adopted the Trademark Law, the Patent Law and the Copyright Law in 1982, 1984 and 1990, respectively. At the international level, China further acceded to the Paris Convention for the Protection of Industrial Property in 1984, the Berne Convention for the Protection of Literary and Artistic Works in 1992 and the Convention for the Protection of Producers of Phonograms against Unauthorized Duplication of Their Phonograms (Geneva Convention) in 1993.

Until the creation of the modern Chinese intellectual property system, all the intellectual property laws and regulations in the country were either required by the 'unequal treaties' signed after China's defeat in the Opium War (1839-42) ${ }^{3}$ or borrowed from the socialist incentive models in the Soviet Union. ${ }^{4}$ As a result, the pre-existing intellectual property laws and regulations in China were mostly transplants from the West with limited modifications. Although policymakers and commentators have widely noted how Confucianism has militated against intellectual property reform in China, ${ }^{5}$ a large part of the resistance actually originated from the socialist ethos and incentive models, which were neither Confucian nor Chinese.

The second phase, the standardization and customization phase, began when China made preparations to join the WTO. Although the country claimed that it belonged to the international trading body by virtue of the Nationalist (Kuomintang) government's founding membership in the General Agreement on Tariffs and Trade (GATT), China was not allowed to join the WTO until the launch of the Doha Development Round of Trade Negotiations in November 2001. On 11 December 2001, China formally became the 143rd member of the international trading body.

\section{Ibid 5-13.}

3. PK Yu, 'Piracy, Prejudice, and Perspectives: An Attempt to Use Shakespeare to Reconfigure the U.S.-China Intellectual Property Debate' (2001) 19 Boston U International LJ 1, 5-8.

4. WP Alford, To Steal a Book Is an Elegant Offense: Intellectual Property Law in Chinese Civilization (Stanford UP, Stanford, CA 1995) 56-65.

5. On the different views regarding Confucianism and intellectual property law reform, see ibid; K Shao, 'The Global Debates on Intellectual Property: What If China Is Not a Born Pirate?' (2010) Intellectual Property Quarterly 341; PK Yu, 'Intellectual Property and Confucianism', in I Calboli and S Ragavan (eds), Diversity in Intellectual Property: Identities, Interests, and Intersections (CUP, New York 2015). 
In the run-up to the WTO accession, China amended its patent law in August 2000 and its copyright and trademark laws in October 2001. The primary goal of these 'millennium' amendments was to ensure that the Chinese intellectual property system complied with the standards laid down by the TRIPS Agreement. Nevertheless, many of the provisions in these amendments also sought to adapt the system to rapidly changing local conditions (guoqing). ${ }^{6}$ These conditions included 'the Chinese leaders' changing attitude towards the rule of law, the emergence of private property rights and local stakeholders, the increasing concerns about ambiguities over relationships in state-owned enterprises, and the government's active push for modernization'. ${ }^{7}$

The third phase, the indigenization and transformation phase, began after China joined the WTO. Although China struggled in the initial transition period and kept a rather low international profile, it became more assertive a few years into the WTO membership. ${ }^{8}$ In June 2008, the State Council released an Outline of the National Intellectual Property Strategy, emphasizing the concept of zizhu zhishi chanquan (which can be roughly translated as 'independent intellectual property'). ${ }^{9}$ Two years later, the State Intellectual Property Office (SIPO) followed up by releasing a highly ambitious document detailing its National Patent Development Strategy for 2011-2020, which set the annual target for patent applications at 2 million by 2015. Although David Kappos, the then-director of the US Patent and Trademark Office, found the announced target 'mind-blowing', ${ }^{10}$ that figure was surpassed in 2012, three years before the target date. ${ }^{11}$

Going hand in hand with these policy announcements were wholesale amendments to the three major intellectual property statutes. In December 2008, China amended the Patent Law for the third time. Five years later, China also amended the Trademark Law, again for the third time. At the time of writing, the country has not yet completed its amendment to the Copyright Law, but three drafts have already been examined and publicly disclosed. It is anticipated that the amendment will be adopted in the near future, thereby completing another total overhaul of the Chinese intellectual property system.

For many commentators - both inside and outside China - the amendments in the third phase were rather different from those in the first two phases. In the latest phase, China has intentionally moved away from the transplant model to develop its own intellectual property laws and regulations. As Guo He noted in regard to the third amendment to the Chinese Patent Law, 'The impetus for the early amendments came from outside, whilst the need for the third amendment originated from within

6. PK Yu, 'From Pirates to Partners (Episode II): Protecting Intellectual Property in PostWTO China' (2006) 55 American U L Rev 901, 914-23.

7. Ibid 908.

8. HS Gao, 'China's Participation in the WTO: A Lawyer's Perspective' (2007) 11 Singapore Year Book of International Law 41, 69; PK Yu, 'The Middle Kingdom and the Intellectual Property World' (2011) 13 Oregon Rev of International L 209, 229-37.

9. On the concept of 'zizhu zhishi chanquan', see D Prud'homme, Dulling the Cutting-Edge: How Patent-Related Policies and Practices Hamper Innovation in China (European Chamber of Commerce, Shanghai 2012) 79; PK Yu, 'Five Oft-repeated Questions about China's Recent Rise as a Patent Power' (2013) Cardozo L Rev De Novo 78, 93-5.

10. S Lohr, 'When Innovation, Too, Is Made in China' New York Times (2 January 2011) BU3. 11. State Intellectual Property Office, 'Table 1 Distribution of Applications for Inventions Received from Home and Abroad', <http://english.sipo.gov.cn/statistics/2012/12/201303/ t20130315_788166.html> accessed 18 September 2017; State Intellectual Property Office, 'Table 16 Distribution of Applications for Patents for Utility Model and Design Received from Home and Abroad', <http://english.sipo.gov.cn/statistics/2012/12/201303/t20130315_788149. html> accessed 18 September 2017. 
China, that is to say, the majority of the third amendment was to meet the needs of the development of the domestic economy and technology originating in China' ${ }^{12}$

At this point, it remains unclear whether the Chinese intellectual property model will differ significantly from its Western counterpart. Nevertheless, China has been very eager to become an innovative power, focusing not just on independent innovation but also on popular innovation. ${ }^{13}$ The country has also proposed amending its patent law for the fourth time. In addition, it is now in the process of revising its Anti-Unfair Competition Law. Because that particular statute has not been amended since 1993 and trade secret issues continue to dominate the US-China intellectual property debate ${ }^{14}$ such revision is likely to be quite significant.

In sum, the development of the Chinese intellectual property system has changed from actively transplanting laws from abroad to introducing amendments that are specifically tailored to rapidly changing local conditions. Although China will continue to borrow from foreign models and experiences, the country's intellectual property system, to a large extent, has already aged beyond the point where it can benefit significantly from copying models from abroad. Instead, the country needs to start exploring models that would best suit its needs, interests, conditions and priorities while figuring out how to improve these models to maximize their benefits.

\section{INTELLECTUAL PROPERTY REFORM}

Since the mid-1980s, the stories about intellectual property developments in China have focused on the country's massive piracy and counterfeiting problems. To address these problems, the US government, in the late 1980s and early 1990s, repeatedly threatened China with a series of economic sanctions, trade wars, non-renewal of most-favourednation status and opposition to its WTO entry. ${ }^{15}$ Those criticisms and threatened actions continue even today. Only recently, the United States Trade Representative launched an investigation of China under Section 301 of the Trade Act of 1974 concerning the laws, policies and practices in the areas of intellectual property, innovation and technology development. $^{16}$

Notwithstanding the perennial focus on piracy and counterfeiting, an ever-growing number of commentators have recognized the slowly changing discourse on intellectual property developments in China, especially in the past few years. While piracy and counterfeiting problems continue to exist, and are unlikely to go away any time soon, ${ }^{17}$ many policymakers and commentators now see China as an innovative power, or at least an

12. H Guo, 'Patents', in R Kariyawasam (ed), Chinese Intellectual Property and Technology Laws (Edward Elgar Publishing, Cheltenham, UK and Northampton, MA, USA 2011) 28.

13. P Li, 'Intellectual Property and Development: Patents, Mass Innovation and the Xiaokang Society' (2017) 8 WIPO J 97.

14. Office of the United States Trade Representative, 2014 Special 301 Report (2014) 32; PK Yu, 'Trade Secret Hacking, Online Data Breaches, and the China Cyberthreat' (2015) Cardozo L Rev De Novo 130, 130-36.

15. PK Yu, 'From Pirates to Partners: Protecting Intellectual Property in China in the Twentyfirst Century' (2000) 50 American U L Rev 131, 140-51.

16. Office of the United States Trade Representative, 'USTR Announces Initiation of Section 301 Investigation of China', <https://ustr.gov/about-us/policy-offices/press-office/press-releases/ 2017/august/ustr-announces-initiation-section> accessed 20 September 2017.

17. PK Yu, 'Intellectual Property, Asian Philosophy and the Yin-Yang School' (2015) 7 WIPO J 1, 12-13. 
emerging one. ${ }^{18}$ They also explore whether the innovation in China complements or rivals the innovation in other parts of the world. ${ }^{19}$

Based on the 2016 WIPO statistics, China had the world's third largest number of international applications filed through the Patent Cooperation Treaty, behind only the United States and Japan. ${ }^{20}$ Among corporate applicants, the China-based ZTE Corporation and Huawei Technologies also had the first and second largest volume of international patent applications, respectively. For the same year, China ranked fourth in the number of international trademark applications under the Madrid System. ${ }^{21}$

At the domestic level, the total number of patent applications has also been highly impressive. Based on SIPO's statistics, in 2016 China processed nearly 3.5 million patent applications, about 3.3 million of which originated from local inventors. ${ }^{22}$ While these figures included three different types of patents - for inventions, designs and utility models - the total number of invention patents issued in China in that year (404 208) compared favourably with the total number of utility patents issued in the United States in the same year (304 568). ${ }^{23}$

To be sure, questions have arisen over the quality of patents issued in China. ${ }^{24}$ Nevertheless, Chinese firms have been actively applying for and obtaining patents in both the European Patent Office and the US Patent and Trademark Office. Based on the 2015 statistics, Chinese residents were behind only those of Japan, South

18. Eg JL Orcutt and H Shen, Shaping China's Innovation Future: University Technology Transfer in Transition (Edward Elgar Publishing, Cheltenham, UK and Northampton, MA, USA 2011); S Rein, The End of Cheap China: Economic and Cultural Trends That Will Disrupt the World (John Wiley \& Sons, Hoboken, NJ 2012); DF Simon and C Cao, China's Emerging Technological Edge: Assessing the Role of High-End Talent (CUP, Cambridge and New York 2009); RP Suttmeier and X Yao, 'China's IP Transition: Rethinking Intellectual Property Rights in a Rising China' (2011) The National Bureau of Asian Research, NBR Special Report No. 29; PK Yu, 'The Rise and Decline of the Intellectual Property Powers' (2012) 34 Campbell L Rev 525, 529-32.

19. Eg D Breznitz and M Murphree, Run of the Red Queen: Government, Innovation, Globalization, and Economic Growth in China (Yale UP, New Haven, CT 2011); Y Tan, Chinnovation: How Chinese Innovators Are Changing the World (John Wiley \& Sons, Singapore 2011); M Zeng and PJ Williamson, Dragons at Your Door: How Chinese Cost Innovation Is Disrupting Global Competition (Harvard Business School Press, Boston, MA 2007).

20. World Intellectual Property Organization, 'Who Filed the Most PCT Patent Applications in 2016?', <http://www.wipo.int/export/sites/www/ipstats/en/docs/infographic_pct_2016.pdf> accessed 10 August 2017.

21. World Intellectual Property Organization, 'Who Filed the Most Madrid Trademark Applications in 2016?', <http://www.wipo.int/export/sites/www/ipstats/en/docs/infographic_ madrid_2016.pdf> accessed 10 August 2017.

22. State Intellectual Property Office, 'Table 1 Distribution of Inventions Received from Home and Abroad', <http://english.sipo.gov.cn/statistics/2016/12/201704/t20170407_1309327.html> accessed 18 September 2017; State Intellectual Property Office, 'Table 16 Distribution of Applications for Patents for Utility Model and Design Received from Home and Abroad', <http://english.sipo.gov.cn/statistics/2016/12/201704/t20170407_1309310.html> accessed 18 September 2017.

23. Compare State Intellectual Property Office, 'Table 4 Distribution of Grants for Inventions Received from Home and Abroad', <http://english.sipo.gov.cn/statistics/2016/12/201704/ t20170407_1309323.html > accessed 18 September 2017, with US Patent and Trademark Office, Performance and Accountability Report - Fiscal Year 2016 (2017) 178.

24. M Liang, 'Chinese Patent Quality: Running the Numbers and Possible Remedies' (2012) 11 John Marshall Rev of Intellectual Property L 478. 
Korea and Germany in terms of the patent applications filed in the United States. ${ }^{25}$ According to the European Patent Office, about 15 per cent of its patent filings in 2016 originated in China, a figure behind only the United States and Japan. ${ }^{26}$

In view of these many exciting and impressive developments, one cannot help but wonder whether China could have undertaken more intellectual property reform in the past 35 years. To be sure, policymakers and industry associations have a strong tendency to compare China with developed countries - or, worse, against a country with ideal levels of effective intellectual property protection and enforcement. Such comparisons were particularly prevalent in the late 1980s and early 1990s and have continued even today. Yet, considering that China is now reaching only its mid-thirties, China was technically still a child or teenager two or three decades ago. In retrospect, it is not difficult to see why many Chinese policymakers and commentators have found the past criticisms of their intellectual property system unfair and unrealistic.

As I noted in a previous work, a critical challenge in comparative intellectual property analysis is to locate the tertium comparationis (what to compare). ${ }^{27}$ Consider, for example, the state of intellectual property protection and enforcement in China in 2005, at a point when the United States actively debated whether it should file a WTO complaint against China concerning its TRIPS violations. At that time, the Chinese intellectual property system had only existed for about two decades. A close look at the comparative data would make one question the usefulness and relevance of comparing China with other countries with decades, or even centuries, of intellectual property developments. More specifically, if the Business Software Alliance found that France and Italy had a software piracy rate of 45 per cent and 50 per cent, respectively, despite having had more than two centuries of intellectual property developments, ${ }^{28}$ how problematic was it for China to have a piracy rate of 90 per cent considering that its modern intellectual property system was not even instituted until the early 1980s? ${ }^{29}$ There is simply no evidence that China could have developed its intellectual property system more quickly and successfully than France, Italy or other Western developed countries.

From a standpoint of intellectual property reform, asking whether China could have achieved more in the past three decades is important. After all, if China, with all its resources, centralized structures and economic growth, still could not make all the improvements demanded by foreign intellectual property industries and their supportive governments, how likely would it be that smaller or weaker developing countries could do the same? From having 'only four patents and six inventor certificates ... granted' between 1950 and $1963^{30}$ to now joining the United States and Japan as the world's leaders in international patent applications, China has achieved what no other country has done before. To some extent, China's accomplishments may suggest the limits of intellectual property reform in the developing world.

Today, there is still a frequent assumption on the part of politicians, policymakers and industry leaders that countries can always improve intellectual property protection and

25. US Patent and Trademark Office (n 23) 184.

26. 'European Patent Filings per Country of Origin', <https://www.epo.org/about-us/annualreports-statistics/annual-report/2016/statistics/patent-filings.html\#tab3> accessed 18 September 2017.

27. PK Yu, 'Enforcement, Economics and Estimates' (2010) 2 WIPO J 1, 13.

28. Business Software Alliance and International Data Corporation, Second Annual BSA and IDC Global Software Piracy Study (2005) 8.

29. $\mathrm{Yu}(\mathrm{n} 6) 927$.

30. P Ganea and T Pattloch, Intellectual Property Law in China (Kluwer Law International, The Hague 2005) 3. 
enforcement by tightening criminal measures, increasing enforcement resources and enlarging the scope of legal protection. While this assumption may have been valid for countries seeking to build their intellectual property systems from the ground up, similar reform is unlikely to be effective for countries reaching, or having reached, the point of diminishing returns. A greater insistence on the usual demands for tougher laws and penalties may not only fail to result in a significant increase in actual protection, but may also backfire by increasing enforcement and compliance costs while creating resentment among the local populace.

Thus, instead of repeatedly demanding that developing countries adopt higher intellectual property standards regardless of local conditions, it may be useful to explore whether these countries could improve their underlying environments to enable more effective protection and enforcement of intellectual property rights. ${ }^{31}$ In the Chinese context, for instance, reforms can be developed to strengthen such enabling features as 'a consciousness of legal rights, respect for the rule of law, an effective and independent judiciary, a well-functioning innovation and competition system, sufficiently-developed basic infrastructure, a critical mass of local stakeholders, and established business practices'. ${ }^{32}$

Finally, countries do not just follow the paths trodden by others. If we have learned anything from China since its WTO accession, it is that countries will eventually have to set their own paths if they want to succeed. ${ }^{33}$ Because the path set by China has differed significantly from the paths that were once taken by today's developed countries, that path has raised interesting questions concerning whether other developing countries should follow what commentators have referred to as the 'Beijing Consensus' ${ }^{34}$ or the 'Beijing Proposal', ${ }^{35}$ as opposed to the Washington Consensus. ${ }^{36}$ The latter is particularly important in the intellectual property area considering that it has provided the model for developing the TRIPS Agreement and other later intentional intellectual property treaties. ${ }^{37}$

31. PK Yu, 'Intellectual Property, Economic Development, and the China Puzzle', in DJ Gervais (ed), Intellectual Property, Trade and Development: Strategies to Optimize Economic Development in a TRIPS Plus Era (1st edn, OUP, Oxford 2007) 213-16.

32. PK Yu, 'TRIPS and Its Achilles' Heel' (2011) 18 J of Intellectual Property L 479, 500.

33. Yu (n 9) 99-100.

34. PK Yu, 'Sinic Trade Agreements' (2011) 44 UC Davis L Rev 953, 1018-22. The term 'Beijing Consensus' was coined by Joshua Ramo, the former Time foreign editor. On the Beijing Consensus, see W Chen (ed), The Beijing Consensus? How China Has Changed Western Ideas of Law and Economic Development (CUP, Cambridge 2017); SA Halper, The Beijing Consensus: How China's Authoritarian Model Will Dominate the Twenty-First Century (Basic Books, New York 2010); J Cooper Ramo, The Beijing Consensus (Foreign Policy Centre, London 2004).

35. A Hu, China in 2020: A New Type of Superpower (Brookings Institution Press, Washington, DC 2011) 17.

36. Coined by John Williamson, the Washington Consensus was derived from recommendations in ten different areas: (1) fiscal deficits; (2) public expenditure priorities; (3) tax reform; (4) interest rates; (5) the exchange rate; (6) trade policy; (7) foreign direct investment; (8) privatization; (9) deregulation; and (10) property rights. J Williamson, 'What Washington Means by Policy Reform', in J Williamson (ed), Latin American Adjustment: How Much Has Happened? (Institute for International Economics, Washington, DC 1990) 7-20.

37. NW Netanel, 'Introduction: The WIPO Development Agenda and Its Development Policy Context', in NW Netanel (ed), The Development Agenda: Global Intellectual Property and Developing Countries (OUP, New York 2009) 2-3; PK Yu, 'The RCEP and Trans-Pacific Intellectual Property Norms' (2017) 50 Vanderbilt J of Transnational L 673, 696-7. 


\section{CHINA}

Although the middle-aged status of the Chinese intellectual property system has provided a unique vantage point for evaluating past criticisms, such a status also pushes us to question the past explanations for a lack of intellectual property protection and enforcement in China. Thus far, many Chinese policymakers and commentators have repeatedly called for more time and patience for their intellectual property system to develop.

Indeed, many policymakers and commentators, especially those from poorer regions, genuinely believe that China has not reached the stage of development to take on higher levels of intellectual property protection and enforcement. Many of them are also painfully aware of the highly uneven distribution of intellectual property-related activities and benefits throughout the country. In 2016, while Jiangsu, Guangdong and Anhui provinces - the provinces with the three largest volumes of patent applications - had a total of 184 632, 155581 and 95963 , respectively, Yunnan, Jilin and Gansu provinces had a total of only 7907, 7537 and 6114, respectively, not to mention those provinces and autonomous regions that had fewer than 4000 applications. ${ }^{38}$

Although the continuous challenges in China deserve serious attention and some sympathy, one cannot ignore the fact that China, as a whole, has already been competing effectively against other countries, including those in the developed world. In fact, if the Chinese intellectual property system is now entering, or approaching, its prime, it is not difficult to understand why policymakers and commentators in other countries have been deeply frustrated by the lack of significant improvements in intellectual property protection and enforcement in China - especially when similar improvements have been, or have begun to be, achieved in other countries at comparable levels of development.

To some extent, the challenge confronting those asking for time and patience in the intellectual property area is similar to the challenge confronting those arguing that China still needs considerable development assistance from the international community. Those requests and arguments, while undeniably valid in certain parts of the country, seem completely out of touch when one takes account of China's position as the world's second largest or largest economy, depending on one's metrics and methodology. ${ }^{39}$ Given the 1.4 billion-high population, China's gross domestic product per capita will always remain low, even if it has actively and successfully competed with others on the aggregate level.

Another development that has undermined the calls for China to have more time and patience in the intellectual property area concerns the country's growing public consciousness of intellectual property rights. Many working-age Chinese have been born since the creation of the Chinese intellectual property system in the early 1980s. Even those who were born before had seen the system developed when they were at primary school, secondary school or university. If we use the terminology advanced by John Palfrey and Urs Gasser regarding 'digital natives' and 'digital migrants', ${ }^{40}$

38. State Intellectual Property Office, 'Table 2 Distribution of [Applications for] Inventions Received from Home 2016', <http://english.sipo.gov.cn/statistics/2016/12/201704/ t20170407_1309326.html> accessed 18 September 2017.

39. JE Stiglitz, 'The Chinese Century' Vanity Fair (January 2015), <https://www.vanityfair. com/news/2015/01/china-worlds-largest-economy> accessed 23 December 2016.

40. J Palfrey and U Gasser, Born Digital: Understanding the First Generation of Digital Natives (Basic Books, New York 2008). 
many Chinese can be classified as either 'intellectual property natives' or 'intellectual property migrants'. Although unfamiliarity with intellectual property rights was once a common explanation - or, for some, an annoying excuse - for a lack of respect for intellectual property rights, the Chinese today are no longer as unfamiliar with intellectual property rights as their parents or grandparents.

Noting this growing understanding and consciousness among the Chinese populace is important because public awareness plays a critically important role in increasing the actual protection of intellectual property rights. ${ }^{41}$ Law and development scholars have repeatedly highlighted the gap between 'law in books' and 'law in action' ${ }^{42}$ However, one cannot overlook what one scholar has described as 'law-in-the-mind' ${ }^{43}$ Because effective protection and enforcement of intellectual property rights depends on underlying public support, an inquiry into the legal consciousness of the local populace can be quite important. ${ }^{44}$ To some extent, this inquiry brings to mind a similar inquiry made by noted Chinese scholar Stanley Lubman. Through an insightful exchange with a taxi driver, Lubman illustrated vividly that ordinary citizens in China 'understood some basic concepts of the rule of law'. ${ }^{45}$

In sum, it is increasingly difficult for Chinese policymakers and commentators to argue that their intellectual property system should be held to a lower standard due to its youth and immaturity. For these policymakers and commentators, such a growing difficulty can actually be a blessing in disguise, as it will force them to confront the country's challenges head-on and thereby explore ways to improve the intellectual property system. Indeed, if China is to become an innovative country as envisioned in the 2008 National Intellectual Property Strategy, or if it is to avoid what policymakers and commentators have referred to as the 'middle-income trap', ${ }^{46}$ China will have to actively develop its intellectual property system to maximize its competitive and comparative advantage.

\section{TRIPS AGREEMENT}

Since the adoption of the TRIPS Agreement in April 1994, commentators have advanced a number of narratives to describe the agreement's historical origins. Among these narratives, the most widely accepted is the bargain narrative, which takes into account the wide range of compromises struck in the Uruguay Round of Multilateral Trade Negotiations. ${ }^{47}$

41. $\mathrm{Yu}(\mathrm{n} 15)$ 221-5.

42. R Pound, 'Law in Books and Law in Action' (1910) 44 American L Rev 12.

43. J Nie, The Enforcement of Intellectual Property Rights in China (Cameron May, London 2006) 24; PK Yu, 'Tales of the Unintended in Copyright Law' (2015) 67 Studies in Law, Politics and Society 1, 16.

44. J Litman, 'Copyright Noncompliance (Or Why We Can't "Just Say Yes" to Licensing)' (1997) 29 New York U J of International Law and Politics 237; TR Tyler, 'Compliance with Intellectual Property Laws: A Psychological Perspective' (1997) 29 New York U J of International Law and Politics 219.

45. S Lubman, 'Looking for Law in China' (2006) 20 Columbia J of Asian L 1, 88.

46. R Peerenboom and T Ginsburg (eds), Law and Development in Middle-Income Countries: Avoiding the Middle-Income Trap (CUP, New York 2014); FG Im and D Rosenblatt, 'MiddleIncome Traps: A Conceptual and Empirical Survey' (2013) World Bank, Policy Research Working Paper No. 6594.

47. PK Yu, 'TRIPS and Its Discontents' (2006) 10 Marquette Intellectual Property L Rev 369, $371-3$. 
These compromises included, most notably, the trade-offs between concessions in agriculture and textiles on the one hand, and increased intellectual property protection and market access on the other.

As widely accepted as the bargain narrative is, however, it does not present a complete picture. It also fails to convince many policymakers and commentators in developing countries. After all, these countries could not have bargained fairly and effectively in the Uruguay Round when concessions were thrust down their throats.

Chinese policymakers and commentators were no exception, especially considering that China was not even allowed to join the WTO in its first seven years. Like their counterparts in other developing countries, they found the bargain narrative highly unconvincing. Instead, many embraced either the coercion narrative or the ignorance narrative. While the former posits that the TRIPS Agreement was imposed upon developing countries against their self-interests, the latter holds that these less powerful countries failed to understand the importance of intellectual property protection during the TRIPS negotiations. ${ }^{48}$

Interestingly, despite having the burden of assuming WTO-plus obligations in intellectual property and other areas, ${ }^{49}$ China has been doing very well since it joined the international trading body. Although one can certainly debate whether the country's success in the intellectual property area actually originated from the WTO or its TRIPS Agreement - an important distinction - the WTO's 'single undertaking' approach has virtually guaranteed that China could not have obtained benefits from non-intellectual property reforms without also implementing TRIPS-based reforms. Moreover, as China moved from the imitation and transplantation phase to the indigenization and transformation phase, it has skilfully deployed 'selective adaptation' strategies to ensure the incorporation of only beneficial features of the TRIPS Agreement without also transplanting its harmful and unsuitable elements. ${ }^{50}$

Notwithstanding the potential positive impact of the WTO and its TRIPS Agreement on China's growing success in the intellectual property area, one cannot overlook the country's repeated and continued resistance to implementing the TRIPS Agreement in the same way as the European Union or the United States did. In fact, some commentators - most notably Frederick Abbott - have described the lax protection and enforcement of intellectual property rights in China as 'benign neglect'. ${ }^{51}$ Although China certainly has benefited from the TRIPS-based intellectual property system, the country would not have reached its current position had it implemented the TRIPS Agreement to the fullest extent.

48. Ibid 373-6.

49. SS Kim, 'China in World Politics', in B Buzan and R Foot (eds), Does China Matter? A Reassessment: Essays in Memory of Gerald Segal (Routledge, London 2004) 49; JY Qin, 'China, India and WTO Law', in M Sornarajah and J Wang (eds), China, India and the International Economic Order (CUP, Cambridge 2010) 173-5.

50. PB Potter, 'China and the International Legal System: Challenges of Participation', in DC Clarke (ed), China's Legal System: New Developments, New Challenges (CUP, Cambridge 2008) 147-8; H Wu, 'One Hundred Years of Progress: The Development of the Intellectual Property System in China' (2009) 1 WIPO J 117, 118-19; PK Yu, 'The Transplant and Transformation of Intellectual Property Laws in China', in N Lee, N Bruun and M Li (eds), Governance of Intellectual Property Rights in China and Europe (Edward Elgar Publishing, Cheltenham, UK and Northampton, MA, USA 2016) 26.

51. FM Abbott, 'Toward a New Era of Objective Assessment in the Field of TRIPS and Variable Geometry for the Preservation of Multilateralism' (2005) $8 \mathrm{~J}$ of International Economic L 77, 100. 
Ultimately, what actual benefits the TRIPS Agreement has provided depends largely on empirical analysis. Because this analysis will inevitably involve counterfactual reasoning, it will not be easy to prove one way or another. In fact, it is very possible that the finding will lie somewhere in between: while the WTO and its TRIPS Agreement have helped China succeed, they have also threatened to slow down its growth. Thus, it will be interesting to see whether other developing countries should follow China's lead in resisting the adoption of high intellectual property standards until their domestic conditions have improved to the point where such higher standards could become beneficial.

Finally, even though this article focuses on the point when the Chinese intellectual property system hits 35, we cannot forget that the TRIPS Agreement was adopted only less than 25 years ago. Using the metaphors advanced in this article, the TRIPS Agreement has not even entered its prime or approached its middle age.

During the negotiation of the TRIPS Agreement in the late 1980s and early 1990s and shortly after its entering into force in the mid-1990s, many policymakers and commentators, especially those in the developing world, condemned the agreement for being 'imperialistic', 'coercive' and insensitive to local needs, interests, conditions and priorities. ${ }^{52}$ Today, however, policymakers and commentators seem to have changed their views; they have increasingly viewed the TRIPS Agreement as embodying standards that have been widely accepted by the international community.

This change in perspective can be partly attributed to the developed countries' increasing push for high TRIPS-plus standards through bilateral, regional and plurilateral agreements. Such agreements include not only those free trade or economic partnership agreements established by the European Union and the United States, but also the Anti-Counterfeiting Trade Agreement, the Trans-Pacific Partnership Agreement and the proposed agreements for the Transatlantic Trade and Investment Partnership and Regional Comprehensive Economic Partnership. While TRIPS standards may still be higher than many countries have preferred, they are far more accommodating than the TRIPS-plus standards found in current bilateral, regional and plurilateral agreements. As Susan Sell observed, the TRIPS Agreement 'looks like a relatively timid and permissive agreement' when it is compared against the newly negotiated agreements. ${ }^{53}$

Even worse for developing countries, those TRIPS-plus agreements may ultimately prevent these countries from taking the same position that China, India and other emerging countries took when they were still developing countries. To be sure, China's accession arrangements required it to take on WTO-plus obligations, beyond what was required of other developing country members. Nevertheless, the policy space China had in the early 2000s was still far wider than what is now available to developing countries under TRIPS-plus agreements.

Given the increasing constraints posed by these agreements and the continuous shrinking of policy space, one cannot help but wonder whether China, India and other emerging countries - which I have referred to collectively as 'middle intellectual

52. E Assafa, 'The Paradox of Intellectual Property Lawmaking in the New Millennium: Universal Templates as Terms of Surrender for Non-industrial Nations; Piracy as an Offshoot' (2002) 10 Cardozo J of International and Comparative L 47; MA Hamilton, 'The TRIPS Agreement: Imperialistic, Outdated, and Overprotective' (1996) 29 Vanderbilt J of Transnational L 613; AS Oddi, 'TRIPS-Natural Rights and a "Polite Form of Economic Imperialism"" (1996) 29 Vanderbilt J of Transnational L 415.

53. SK Sell, 'TRIPS Was Never Enough: Vertical Forum Shifting, FTAs, ACTA, and TPP' (2011) 18 J of Intellectual Property L 447, 448. 
property powers' ${ }^{54}$ - might have been the last group of countries that could benefit from TRIPS-based intellectual property reform. If we intend to allow other developing countries to follow the Chinese or Indian model of intellectual property reform, we may need to start looking for ways to enlarge TRIPS flexibilities to ensure that those countries that have not yet attained the developmental levels of China, India or other emerging countries can still have the much-needed policy space to transform their economies.

\section{CONCLUSION}

As the Chinese intellectual property system hits 35 , this milestone has provided important insights into our understanding of intellectual property law reform - in particular, what such reform can and cannot deliver. China is not just a hot topic on which many scholars have researched and with which many policymakers and industry groups have engaged; rather, it is a paradigmatic example through which one can develop a better and deeper understanding of international intellectual property law and policy.

Studying the Chinese intellectual property system when it hits 35 has another benefit: it provides a more nuanced picture of intellectual property developments in China - past, present and future. For the Chinese and their sympathizers, this milestone has made it difficult for them to continue to claim that China needs more time and patience to develop its intellectual property system. For critics, this milestone also questions whether China could have achieved more reform than it already has in the past three decades.

Finally, and perhaps somewhat unexpectedly, the success China has achieved in the past 35 years may have salvaged the reputation of the TRIPS Agreement. Such success not only shows that the agreement is not as coercive as many have claimed, but also helps make the agreement legitimate in the eyes of developing country policymakers and commentators. In fact, if the agreement can be implemented in ways that benefit developing countries, it can help generate the intellectual property reform needed to enable these countries to catch up with their more developed counterparts.

54. PK Yu, 'The Middle Intellectual Property Powers', in Peerenboom and Ginsburg (n 46). 